\title{
Antimicrobial and antifungal activities of the extracts and essential oils of Bidens tripartita
}

\author{
Monika Tomczykowa $^{1}$, Michał Tomczyk ${ }^{1}$, Piotr Jakoniuk ${ }^{2}$, Elżbieta Tryniszewska ${ }^{2}$ \\ ${ }^{1}$ Department of Pharmacognosy, ${ }^{2}$ Department of Microbiological Diagnostics, \\ Faculty of Pharmacy, Medical University of Białystok, Poland
}

\begin{abstract}
The aim of this study was to determine the antibacterial and antifungal properties of the extracts, subextracts and essential oils of Bidens tripartita flowers and herbs. In the study, twelve extracts and two essential oils were investigated for activity against different Gram-positive Bacillus subtilis, Micrococcus luteus, Staphylococcus aureus, Gram-negative bacteria Escherichia coli, E. coli ( $\beta$-laktamase+), Klebsiella pneumoniae (ESBL+), Pseudomonas aeruginosa and some fungal organisms Candida albicans, C. parapsilosis, Aspergillus fumigatus, A. terreus using a broth microdilution and disc diffusion methods. The results obtained indicate antimicrobial activity of the tested extracts (except butanolic extracts), which however did not inhibit the growth of fungi used in this study. Bacteriostatic effect of both essential oils is insignificant, but they have strong antifungal activity. These results support the use of $B$. tripartita to treat a microbial infections and it is indicated as an antimicrobial and antifungal agent, which may act as pharmaceuticals and preservatives.
\end{abstract}

Key words: Bidens tripartita - Asteraceae - Antimicrobial and Antifungal activities - Plant extracts - Essential oil

\section{Introduction}

The genus Bidens L. (Asteraceae) is mainly represented in Poland by two species $B$. cernua and B. tripartita [1-4]. The herb of $B$. tripartita, commonly known as bur-marigold, is used in folk medicine as a diuretic, sudorific and an anti-inflammatory agent. It stimulates the immunological system. Bur-marigold herb is also an excellent remedy for ruptured blood vessels and bleeding of every description. It is very useful in the treatment of skin diseases, in treating fevers, gravel, stone, and bladder and kidney troubles $[5,6]$. The methylene chloride extract of $B$. tripartita has demonstrated to have high activity in the inhibition of cancer L1210 (mouse leukemia) cells and against thrombin [7]. Extensive phytochemical studies on B. tripartita have shown the presence of flavonoids [8-11], coumarins [12], essential oil [13], polysaccharides, carotenoids, -lactones, amines and mineral elements $[10,14]$. In the petroleum extract of the herb of burmarigold, triterpenes, unsaturated aliphatic hydrocarbons, esters of fatty acids and sterols, with dominating

Correspondence: Michał Tomczyk, Department of Pharmacognosy, Faculty of Pharmacy, Medical University of Białystok, ul. Mickiewicza 2a, 15-230 Białystok, Poland; tel. (+4885) 74685692, fax.: (+4885) 74685614, e-mail: tomczyk@umwb.edu.pl stigmasterol, were identified. The green parts of $B$. tripartita afforded the identification of polyacetylenic compounds, linoleic acid and ocimene [15]. Antioxidant activities of extracts from herbs and flowers and pure flavonoids: flavanomarein (isookanin 7-O-glucoside), cynaroside (luteolin 7-O-glucoside) and luteolin, which had been isolated from this plant, were evaluated by electron paramagnetic resonance (EPR) spectroscopy using stable 1,1-diphenyl-2-picrylhydrazyl (DPPH) radical [16]. The report describes the antibacterial and antifungal properties of the extracts and essential oils of Bidens tripartita against numerous bacterial and fungal strains.

\section{Materials and methods}

Plant material. Bur-marigold flowers and herbs were collected in the Bielsk Podlaski area (Poland) in August 2001. The identification of the voucher specimen was carried out by Dr. J. Nazaruk (Medical University of Białystok). A voucher specimen of plant (No. BT97005) has been deposited at the herbarium of the Department of Pharmacognosy, Medical University of Białystok, Poland.

Essential oils and plant extracts preparation. The essential oil $(\mathrm{BTHO})$ was hydrodistilled $(3 \mathrm{~h})$ from the freshly picked flowering aerial parts of the herb (500 g) using a Deryng-type apparatus. The oil (BTFO) was obtained also from dried flower heads $(210 \mathrm{~g})$ using the same distillation method [13].

Dried and powdered B. tripartita flowers (BF) and herb (BH) were subjected to several extraction procedures: water, 
methanol/water, acetone/water and methanol extraction. In all cases, $15 \mathrm{~g}$ samples of plant material were used for extraction. Water extracts were prepared by pouring $100 \mathrm{ml}$ of hot distilled water on the samples and left at room temperature for $20 \mathrm{~min}$. The aqueous extracts were filtered off and then evaporated to dryness on a rotary vacuum evaporator to afford $\mathrm{BF} 1$ and $\mathrm{BH} 1$.

Methanol/water extracts were obtained by heating powdered flowers (or herb) in $400 \mathrm{ml}$ of 1:1 (v/v) methanol/water with agitation under reflux for $2 \mathrm{~h}$. After filtration, the residue was extracted again with the same solvent. The combined extract was evaporated to dryness in vacuuo affording BF2; the same extraction procedure was performed with herb afforded $\mathrm{BH} 2$.

Acetone/water $(1: 1 \mathrm{v} / \mathrm{v})$ extracts were obtained by heating the samples in that solvent $(400 \mathrm{ml})$ under reflux for $2 \mathrm{~h}$. The extraction was repeated and the combined extract BF3 (BH3) was evaporated to dryness.

Prior to methanol extraction, dried plant materials: flowers (BTF) or herb (BTH) were treated with petrol and $\mathrm{CHCl}_{3}$ in a Soxhlet apparatus. The plant residue was further extracted with $3 \times$ $500 \mathrm{ml}$ methanol and the combined extracts were evaporated under reduced pressure. The residue redissolved in $50 \mathrm{ml} \mathrm{H}_{2} \mathrm{O}$ was successively partitioned between diethyl ether (subextracts BTF1 and BTH4), ethyl acetate (subextracts BTF2, BTH5) and n-BuOH (subextracts BTF3, BTH6).

Phytochemical screening. The content of essential oil in the fresh herb (BTHO) and in the flower heads (BTFO) was measured according to the method described in Polish Pharmacopoeia VI [17]. The composition of oils from B. tripartita was analyzed by gas chromatography (GC) and gas chromatography/mass spectroscopy (GC/MS) methods [13]. The total content of tannins was determined in the flowers and herbs from $B$. tripartita using the weight method with hide powder recommended by German Pharmacopoeia DAB 10 [18]. The total flavonoid content in flowers and herb of $B$. tripartita was determined by the spectrophotometric - Christ-Müller's method with modifications according to Polish Pharmacopoeia VI [16,17].

Microbiological studies. The tested organisms used in this study were as follows:

1. Gram-positive bacteria: Bacillus subtilis ATCC 6633, Micrococcus luteus ATCC 9391, Staphylococcus aureus ATCC 6538.

2. Gram-negative bacteria: Escherichia coli ATCC 25922, E. coli ATCC 35218 ( $\beta$-lactamase+), Klebsiella pneumoniae ATCC 700603 (ESBL+), Pseudomonas aeruginosa ATCC 27853.

3. Fungi: Candida albicans ATCC 10231, C. parapsilosis ATCC 22019, Aspergillus fumigatus, A. terreus.

Aspergillus fumigatus and Aspergillus terreus strains were isolated from a selected of patients with aspergillosis and identified morphologically [19]. All bacterial strains grown on Mueller-Hinton agar plates for $18 \mathrm{~h}$ at $37^{\circ} \mathrm{C}$ were suspended in saline to the density of $0.5 \mathrm{McF}$ arland scale and then diluted a hundred times with Mueller-Hinton broth to give $10^{6} \mathrm{CFU} / \mathrm{ml}$. Fungi were grown on Sabouraud dextrose agar plates at $35^{\circ} \mathrm{C}$ - Candida for $48 \mathrm{~h}$, and Aspergillus for 7 days - than yeast cells and conidia of Aspergillus were suspended in saline and adjusted spectrophotometrically to the desired inoculum. The media were purchased from Oxoid (Unipath S.p.A., Milan, Italy).

Broth microdilution method. The minimum inhibitory concentration (MIC) of all extracts, subextracts and essential oils for antibacterial testing was determined by broth microdilution method according to that approved by NCCLS [20]. Each fraction was first dissolved - in $1 \mathrm{ml}$ of dimethyl sulfoxide (DMSO), than in Mueller-Hinton broth to a $200 \mathrm{mg} / \mathrm{ml}$ concentration. Two-fold serial dilutions in 1001 of Mueller-Hinton broth were made, then $100 \mu \mathrm{l}$ of liquid suspension of the reference strains was added to give final inoculum of $0.5 \times 10^{6} \mathrm{CFU} / \mathrm{ml}$. The antifungal activity was estimated as described in accordance with NCCLS standards [21] with the following modifications: Sabouraud medium was used for fungi cultivations; the activity of oils was estimated in RPMI medium (Biomed, Lublin, Poland) using $103 \mathrm{CFU} / \mathrm{ml}$ fungi suspensions for inoculation.

Disc diffusion test. For antimicrobial and antifungal testing solutions of each extract, subextract and volatile oil were prepared in the same way as in broth microdilution method. Broth cultures $(0.1$ $\mathrm{ml}$ ), adjusted to yield approximately $10^{7} \mathrm{CFU} / \mathrm{ml}$ for bacteria and $10^{4} \mathrm{CFU} / \mathrm{ml}$ for yeasts, were inoculated on plates containing Mueller-Hinton and Sabouraud medium respectively. Holes $(5 \mathrm{~mm}$ diameters) were cut in the inoculated agar plates. The solutions of tested extracts, subextracts and oils $(50 \mu \mathrm{l})$ were spotted onto such prepared plates $(10 \mathrm{mg}$ per hole) and diameter of inhibition zone was measured after $18 \mathrm{~h}$ incubation at $35^{\circ} \mathrm{C}$. Antibacterial and antifungal activity was expressed as the mean of inhibition diameters $(\mathrm{mm})$ produced by the plant extract, subextract and essential oils.

\section{Results and discussion}

The amount of oil calculated for the fresh herb (BTHO) was $0.12 \%(\mathrm{v} / \mathrm{w})$ and $0.06 \%$ for the flower heads (BTFO). The major constituents of the oil of flower heads were p-cymene $(16.6 \%)$, -caryophyllene oxide $(6.0 \%)$ and humulene epoxide II $(5.3 \%)$. The main constituents of the oil from fresh herb were alloocimene (38.3\%), (Z)- $\beta$-ocimene (30.6\%) and $\alpha$-phellandrene $(8.5 \%)$ [13].

The herbs of bur-marigold are characterized by greater than that of the flowers amount of tannins and resulted to $9.25 \%$ and $6.50 \%$, respectively. The results obtained for flavonoid content calculated for hyperoside were $0.93 \%$ for the flowers and $1.85 \%$ for the herb. The results calculated for quercetin were showed to be lower and were for the flowers and herb $0.65 \%$ and $1.23 \%$, respectively. According to quantitative HPLC analysis, the dominating flavonoid in the herb of B. tripartita is cynaroside and in flower heads - flavanomarein [16].

The MICs of extracts, subextracts and oils obtained by the broth microdilution method are shown in Table 1 . The results obtained by disc diffusion test are given in Table 2. Analyzed extracts and subextracts, except butanolic extracts, inhibited growth of Gram-positive bacteria. The diethyl ether subextract from the herb of B. tripartita showed the strongest antimicrobial activity against Gram-positive bacteria $(\mathrm{MIC}=1.5 \div 3.1$ $\mathrm{mg} / \mathrm{ml}$ ) and almost none in case of Gram-negative bacteria. Similar activity against Gram-positive bacteria for diethyl ether subextract obtained from flowers of bur-marigold and low bacteriostatic effect on E. coli $(\beta$-lactamase +$)$ and $K$. pneumoniae (ESBL +$)($ Gramnegative) was observed. Butanolic subextracts from the flowers and the herbs of $B$. tripartita, according to MIC $>100 \mathrm{mg} / \mathrm{ml}$, showed the lowest antimicrobial activity. The remainder of the investigated extracts and subextracts were moderately active against Gram-positive bacteria with efficacy lowest than diethyl ether subextracts. Klebsiella pneumoniae, and both 
Table 1. Minimum inhibitory concentration (MICs) of the material tested against different micro-organisms

\begin{tabular}{|c|c|c|c|c|c|c|c|c|c|c|c|c|c|c|}
\hline \multirow{3}{*}{ Micro-organisms } & \multicolumn{14}{|c|}{ Tested material (MTC $\mathrm{mg} \mathrm{ml}^{-1}$ ) } \\
\hline & \multicolumn{6}{|c|}{ Extracts } & \multicolumn{6}{|c|}{ Subextracts } & \multicolumn{2}{|c|}{ Essential oils } \\
\hline & $\mathrm{BF} 1$ & $\mathrm{BH} 1$ & BF2 & $\mathrm{BH} 2$ & BF3 & $\mathrm{BH} 3$ & BTF1 & BTH4 & BTF2 & BTH5 & BTF3 & BTH6 & BTFO & BTHO \\
\hline \multicolumn{15}{|c|}{ Gram-positive bacteria } \\
\hline M. luteus & 1.5 & 3.1 & 3.1 & 6.2 & 1.5 & 1.5 & 1.5 & 1.5 & 3.1 & 3.1 & $>100$ & $>100$ & 3.1 & 12.5 \\
\hline Staph. aureus & 6.2 & 1.5 & 3.1 & 3.1 & 3.1 & 3.1 & 1.5 & 1.5 & 3.1 & 6.2 & $>100$ & $>100$ & 1.5 & 6.2 \\
\hline B. subtilis & 3.1 & 3.1 & 3.1 & 3.1 & 1.5 & 6.2 & 3.1 & 3.1 & 3.1 & 12.5 & $>100$ & $>100$ & 3.1 & 12.5 \\
\hline \multicolumn{15}{|c|}{ Gram-negative bacteria } \\
\hline E. coli & $>100$ & 12.5 & 6.2 & 12.5 & 6.2 & 6.2 & $>100$ & $>100$ & $>100$ & $>100$ & $>100$ & $>100$ & 12.5 & $>100$ \\
\hline $\begin{array}{l}\text { E. coli } \\
(\beta \text {-lactamase }+)\end{array}$ & $>100$ & 12.5 & 12.5 & 25 & 6.2 & 25 & 50 & $>100$ & $>100$ & $>100$ & $>100$ & $>100$ & 25 & $>100$ \\
\hline Kl. pneumoniae & $>100$ & 50 & 25 & 25 & 12.5 & 12.5 & 12.5 & $>100$ & $>100$ & $>100$ & $>100$ & $>100$ & $>100$ & $>100$ \\
\hline Ps. aeruginosa & $>100$ & 50 & 50 & $>100$ & 50 & $>100$ & $>100$ & $>100$ & $>100$ & $>100$ & $>100$ & $>100$ & $>100$ & $>100$ \\
\hline \multicolumn{15}{|l|}{ Fungi } \\
\hline C.albicans & $>100$ & $>100$ & $>100$ & $>100$ & $>100$ & $>100$ & $>100$ & $>100$ & $>100$ & $>100$ & $>100$ & $>100$ & 6.2 & 3.1 \\
\hline C.parapsilosis & $>100$ & $>100$ & $>100$ & $>100$ & $>100$ & $>100$ & $>100$ & $>100$ & $>100$ & $>100$ & $>100$ & $>100$ & 12.5 & 6.2 \\
\hline A. fimigatus & $>100$ & $>100$ & $>100$ & $>100$ & $>100$ & $>100$ & $>100$ & $>100$ & $>100$ & $>100$ & $>100$ & $>100$ & 25 & 25 \\
\hline A. terreus & $>100$ & $>100$ & $>100$ & $>100$ & $>100$ & $>100$ & $>100$ & $>100$ & $>100$ & $>100$ & $>100$ & $>100$ & 12.5 & 25 \\
\hline
\end{tabular}

Table 2. Disc diffusion test results

\begin{tabular}{|c|c|c|c|c|c|c|c|c|c|c|c|c|c|c|}
\hline \multirow{3}{*}{ Micro-organisms } & \multicolumn{14}{|c|}{ Tested material (inhibition diameters $(\mathrm{mm})$ ) } \\
\hline & \multicolumn{6}{|c|}{ Extracts } & \multicolumn{6}{|c|}{ Subextracts } & \multicolumn{2}{|c|}{ Essential oils } \\
\hline & $\mathrm{BF} 1$ & BH1 & $\mathrm{BF} 2$ & $\mathrm{BH} 2$ & BF3 & $\mathrm{BH} 3$ & BTF1 & BTH4 & BTF2 & BTH5 & BTF3 & BTH6 & BTFO & BTHO \\
\hline \multicolumn{15}{|l|}{ Gram-positive bacteria } \\
\hline M. luteus & 11 & 16 & 14 & 14 & 15 & 16 & 12 & 16 & 15 & 17 & 0 & 0 & 20 & 12 \\
\hline Staph. aureus & 9 & 17 & 13 & 12 & 14 & 14 & 15 & 16 & 17 & 14 & 0 & 0 & 18 & 10 \\
\hline B. subtilis & 10 & 15 & 11 & 15 & 12 & 16 & 14 & 14 & 15 & 8 & 0 & 0 & 14 & 11 \\
\hline \multicolumn{15}{|l|}{ Gram-negative bacteria } \\
\hline E. coli & 0 & 9 & 8 & 8 & 10 & 10 & 0 & 0 & 0 & 0 & 0 & 0 & 9 & 0 \\
\hline E. $\operatorname{coli}(\beta$-lactamase +$)$ & 0 & 7 & 9 & 9 & 8 & 8 & 0 & 0 & 0 & 0 & 0 & 0 & 0 & 0 \\
\hline Kl. pneumomiae & 0 & 6 & 8 & 8 & 8 & 7 & 0 & 0 & 0 & 0 & 0 & 0 & 0 & 0 \\
\hline Ps. aeruginosa & 0 & 7 & 8 & 6 & 8 & 0 & 0 & 0 & 0 & 0 & 0 & 0 & 0 & 0 \\
\hline \multicolumn{15}{|l|}{ Fungi } \\
\hline C. albicans & 0 & 0 & 0 & 0 & 0 & 0 & 0 & 0 & 0 & 0 & 0 & 0 & 14 & 15 \\
\hline C.parapsilosis & 0 & 0 & 0 & 0 & 0 & 0 & 0 & 0 & 0 & 0 & 0 & 0 & 13 & 17 \\
\hline A. fumigatus & 0 & 0 & 0 & 0 & 0 & 0 & 0 & 0 & 0 & 0 & 0 & 0 & $-{ }^{\mathrm{a}}$ & - \\
\hline A. terreus & 0 & 0 & 0 & 0 & 0 & 0 & 0 & 0 & 0 & 0 & 0 & 0 & - & - \\
\hline
\end{tabular}

a inhibition zone was no greater than $5 \mathrm{~mm}$ 
Escherichia coli strains were lightly inhibited by all investigated fractions except flower aqueous extract. Pseudomonas aeruginosa were shown to be the most resistant organisms, inhibited by the three assayed fractions only. MICs of $>100 \mathrm{mg} / \mathrm{ml}$ for all subextracts suggest to treat those subextracts as non-active against Gram-negative bacteria. Both oils inhibited Gram-positive organisms. The oil obtained from flower heads has activity four-time higher than the oil from the herbs and it also slightly inhibit the growth of both E. coli strains (Gram-negative bacteria). Both essential oils can be acknowledge as inactive against Klebsiella pneumoniae and Pseudomonas aeruginosa. All analyzed extracts and subextracts failed to inhibit the growth of yeast within the experimental concentration range. Both essential oils showed fungistatic effect, the highest was against Candida albicans and Candida parapsilosis; the lowest against Aspergillus fumigatus. Use of plants as remedies in folk medicine, provide a good reason to investigate them scientifically as potential sources of new plant drugs. It is important to prove which plant extracts, subextracts or volatile oils have a biological activity on some specific medical conditions, e.g. antimicrobial and antifungal properties.

The results presented above indicate different spectrum of antimicrobial and antifungal activity of some extracts, subextracts and essential oils obtained from the flowers and herbs of B. tripartita. The diethyl ether subextracts exhibited the widest spectrum and the highest antimicrobial activity, in particular towards Gram-positive bacteria. The butanolic subextracts and essential oils can be regarded as being ineffective against microorganisms. Both volatile oils possess good antifungal activity. The reason for different sensitivity between Gram-positive and -negative bacteria is probably interrelated with their cell wall structure $[22,23]$. The cell walls of Gram-negative bacteria having outer lipopolisaccharide layer are inaccessible for flavonoids which occur in bur-marigold. The highest activity of diethyl ether subextracts is assumed to be a result of additive or synergistic interaction of chemical components of $B$. tripartita. The activity is also associated with the ratio of antimicrobial compounds in the extracts and subextracts. The differences in solvent polarity influences the qualitative and quantitative composition of active compounds in analysed fractions. That suggests a low content of chemical constituents with antimicrobial activity in butanolic subextracts, which results in its inactivity against micro-organisms. High antifungal activity of both essential oils is also very important. These oils could become a possible alternative to synthetic fungicides in the fight against phytopathogenenic fungi. Although chemical composition of oils is well known, the antifungal compounds of the assayed oils are not recognized [13]. Tiophenes, one of the main oils con- stituents, are probably responsible for antifungal activity [24]. Compound-activity relationship for oils components against fungus organisms must be elucidated to explain its antifungal activity.

\section{Conclusion}

In conclusion, two most frequent methods were used in this study to assess antimicrobial and antifungal activity. Although many factors in those methods differ, comparison of the data obtained by disc diffusion test has confirmed the results produced by the broth microdilution method. It confirmed the usefulness of those conventional methods for assessing antimicrobial and antifungal activity of plant extracts, subextracts and volatile oils [25]. Antimicrobial and antifungal activity established in this study fully explains the use of $B$. tripartita flowers and herbs in folk medicine for treatment on mucocutaneous candidosis, also skin diseases and inflammations caused by antimicrobial and fungi organisms. Regardless of the obtained results, there is a need for further investigations directed towards the identification of active components in the extracts as well as determination of their influence on the examined activity.

\section{References}

[ 1] Pawłowski B, Jasiewicz A. Polish Flora. Vol. XII. WarszawaKraków: PWN Press; 1971.

[2] Szafer Wł, Kulczyński St, Pawłowski B. Polish Plants. Vol. II. Warszawa: PWN Press; 1988.

[3] Evans WC. Trease and Evans' Pharmacognosy. LondonPhiladelphia-Toronto Sydney-Tokyo: WB Saunders Company; 1996

[ 4] Tutin TG. Bidens L. In: Heywood VH, Burges NA, Valentine DH, Walters SM, Webb DA, eds. Flora Europaea. vol. IV. Cambridge: University Press; 1996:139-140.

[ 5] Ożarowski A. Lexicon of natural drugs. Katowice: Agencja Wydawnicza COMES; 1993.

[6] Strzelecka H, Kowalski J. Encyclopaedia of Herbal Medicines and Phytotherapy. Warszawa: PWN Press; 2000.

[7] Goun EA, Petrichenko VM, Solodnikov SU, Suhinina TV, Kline MA, Cunningham G., Nguyen C, Miles H. Anticancer and antithrombin activity of Russian plants. J Ethnopharmacol. 2002;81:337-342.

[ 8] Barańska K. Studies on some flavonoids present in herbs of Bidens tripartitus L. Acta Polon Pharm. 1963;20:357-364.

[ 9] Serbin AG, Borisov MJ, Chernobai VT, Kovalev IP, Gordienko VG. Flavonoids of Bidens tripartita. III. Khim Prirod Soedin. 1975;11:144-147.

[10] Isakova TI, Serbin AG, Belikov VV, Chushenko VN. Flavonoids and polysaccharides of Bidens L. species. Rastit Resur. 1986;22:517-523.

[11] Olejniczak S, Ganicz K, Tomczykowa M, Gudej J, Potrzebowski J. Structural studies of 2-(3',4'-dihydroxyphenyl)-7- D-glucopyranos-1-O-yl-8-hydroxy-hroman-4-one in the liquid and solid states by means of 2D NMR spectroscopy and DFT calculations. J Chem Soc, Perkin Transactions 2. 2002;6:1059-1065.

[12] Serbin AG, Zhukov GA, Borisov MJ. Coumarines from Bidens tripartita. Khim Prirod Soedin. 1972;5:668-669. 
[13] Tomczykowa M, Gudej J, Majda T, Góra J. Essential oils of Bidens tripartita L. J Essent Oil Res. 2005;17:632-635.

[14] Ben'ko GN. Effect of gamma-irradiation of Bidens tripartita L. seeds on plant yields and accumulation of biologically active compounds. Rastit Resur. 1983;19:516-520.

[15] Christensen LP, Lam J, Thomasen, T. A chalcones and other constituents of Bidens tripartitus. Phytochem. 1990;29:31553156.

[16] Wolniak M, Tomczykowa M, Tomczyk M, Gudej J, Wawer I. Antioxidant activity of extracts and flavonoids from Bidens tripartita. Acta Polon Pharm. 2007;63:441-447.

[17] Polish Pharmacopoeia FP VI. Warszawa: Polish Pharmaceutical Society; 2002.

[18] DAB 10. Deutsches Arzeneibuch, Amtliche Ausgabe. Stuttgart: Deutcher Apotheker Verlag; 1998.

[19] De Hoog G., Guarro J. Atlas of Clinical Fungi. 1st ed. Baarn and Delft, The Netherlands: Centraalbureau voor Schimmelcultures; 1995.

[20] Jorgensen JH, Tunridge JD, Washington JA. Antibacterial Susceptibility Tests: Dilution and Disk Diffusion Methods. In: Murray PR, Baron EJ, Pfaller MA, Tenover FC, Yolken RH, eds. Manual of Clinical Microbiology. Washington D.C.: American Society for Microbiology; 1999:1526-1543.
[21] Espinel-Ingroff A, White T, Pfaller MA. Antifungal agents and susceptibility tests. In: Murray PR, Baron EJ, Pfaller MA, Tenover FC, Yolken RH, (eds. Manual of Clinical Microbiology. Washington D.C.: American Society for Microbiology; 1999:1690-1652.

[22] Nostro A, Germanö MP, D'Angelo V, Marino A, Cannatelli MA. Extraction methods and bioautography for evaluation of medicinal plant antimicrobial activity. Lett Appl Microbiol. 2000;30:379-384.

[23] Takahashi T, Kokubo R, Sakaino M. Antimicrobial activities of eucalyptus leaf extracts and flavonoids from Eucalyptus maculata. Lett Appl Microbiol. 2004;39:60-64.

[24] Mares D, Tosi B, Poli F, Andreotti E, Romagnoli C. Antifungal activity of Tagetes patula extracts on some phytopathogenic fungi: ultrastructural evidence on Pythium ultimum. Microb Res. 2004;159:295-304.

[25] Hammer KA, Carson CF, Riley TV. Antimicrobial activity of essential oils and other plant extracts. J Appl Microbiol. 1999;86:985-990.

Submitted: 12 January, 2008 Accepted after reviews: 28 March, 2008 